\title{
ATENDIMENTO MÉDICO DE URGÊNCIA NA GRANDE SÃO PAULO'
}

\author{
Sueli Gandolfi Dallari* \\ Sérgio de Moraes Pittelli**

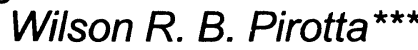 \\ Milca Lopes de Oliveira ${ }^{\star \star \star \star}$
}

\begin{abstract}
RESUMO: Analisa-se a situação do atendimento às emergências médicas na Região Metropolitana de São Paulo, durante o ano de 1999, examinando toda a legislação pertinente, descrevendo o processo de atendimento observado em um Plantão Controlador Regional (PCR) e verificando a adequação dos procedimentos adotados às normas que regem o setor e ao efetivo atendimento da demanda. Foram analisados documentos, realizadas entrevistas e observação do funcionamento do sistema, com um pesquisador no PCR, ao mesmo tempo em que outros acompanhavam os chefes dos plantões nos três hospitais gerais. Descreve-se a história oral da criação do sistema e a rotina dos serviços, onde se verificou que faltavam plantonistas no PCR; que os médicos responsáveis pelos plantões da emergência, não obedeciam a mesma rotina de procedimentos; que muitas pessoas - inclusive os médicos plantonistas - não sabiam o que é o PCR; que muitas vezes a falta de transporte impediu a transferência; que os Serviços de Arquivo Médico e de Estatísticas dos hospitais pesquisados são desatualizados; que faltam recursos materiais e humanos. Apesar de a amostra não permitir generalizações, constatou-se que faltam leitos para UTI Neonatal; que os motivos mais freqüentes para a solicitação de recursos foram: falta de leito, falta ou quebra de equipamento e falta de profissional; que as solicitações tiveram, na quase totalidade dos casos, uma primeira resposta negativa, cujos motivos mais freqüentes eram a falta de vaga, o equipamento não estar disponivel e a indisponibilidade de transporte; que a maioria dos casos chegou ao PCR depois de ter procurado solucionar seu problema por conta própria, alegando a demora no encontro da solução como justificativa para esse comportamento. Com base na normatização do sistema e na análise de experiências internacionais, são feitas sugestões para a eficaz implementação de um sistema metropolitano de atendimento à emergência médica na Grande São Paulo.
\end{abstract}

PALAVRAS-CHAVE: emergência médica; planejamento em saúde; direito sanitário

\footnotetext{
* Professora Titular, Faculdade de Saúde Pública da Universidade de São Paulo; Livre-Docente em Direito Sanitário, Universidade de São Paulo. e-mail: dallari@usp.br Endereço para correspondência: Av. Dr. Arnaldo, 715 CEP 01246-904 São Paulo, SP

** Especialista em Direito Sanitário, Universidade de São Paulo

*** Juiz do Trabalho Substituto do Tribunal Regional do Trabalho $-2^{\text {a }}$ Região

**** Mestre em Saúde Pública

1 Pesquisa realizada para a disciplina HSP-5714 Elaboração e implementação de políticas públicas: o papel das organizações privadas, comunitárias e profissionais, no Curso de Pós-Graduação cm Saúde Pública da Faculdade de Saúde Pública da Universidade de São Paulo, cm 1999.
} 


\section{INTRODUÇÃO}

É notório que o atendimento médico-hospitalar tem como uma de suas principais características o descompasso estrutural entre oferta de recursos e demanda. No caso das urgências, o pronto atendimento do paciente é, muitas vezes, o que separa a vida da morte, a recuperação da saúde da incapacidade física permanente. Com a modificação do perfil epidemiológico da morbi-mortalidade nas áreas metropolitanas, com o crescimento das causas externas, o atendimento de urgência ganha maior relevância. Conforme observam CAMARGO et al. (1995),"Uma das mais importantes alterações que vêm ocorrendo no perfil brasileiro de causas de morte é o crescimento relativo e absoluto da mortalidade por acidentes e violências. Segundo o Sistema de Informações de Mortalidade do Ministério da Saúde, no final dos anos 70, acidentes e violências foram responsáveis por cerca de 60 mil óbitos, constituindo-se, então, no quarto grupo mais importante de causas de morte. Ao longo da década de 80 , enquanto o número total de óbitos aumentuu em cerca de $20 \%$, as causas violentas de morte elevaram-se em 60\%." (pág. 256). O problema da morbi-mortalidade por causas violentas é especialmente preocupante, quando se trata da saúde dos jovens e adolescentes. MAMERI et al. (1998) comentam que "Ao longo dos últimos 15 anos, a mortalidade entre jovens e adolescentes no Estado de São Paulo vem se transformando em um problema cada vez mais acentuado de saúde pública, haja vista o significativo aumento da incidência de óbitos decorrentes de causas violentas nestes grupos etários." (pág. 42).

Os impactos desse quadro sobre o setor da saúde, com destaque para o atendimento de urgência, não é absolutamente desprezível. JORGE (1998) observa que "Embora se saiba que, em nenhuma de suas formas, a violência se constitui em fato gerado pelo setor saúde, essa área vem buscando refletir também sobre o tema e conhecer a complexidade de seus determinantes, a fim de, na sua esfera de competência, contribuir para, na justa medida, encontrar meios adequados para deixá-la, ao menos, em níveis mais suportáveis. Essa causa tem sido responsável por lesar e matar os indivíduos, além de ocasionar um número não pequeno de seqüelas e incapacidades e requerer não poucos recursos do setor saúde, principalmente, na área de atendimento de emergências." (pág. 89). Conforme salienta a autora, o setor saúde não provoca diretamente os problemas decorrentes da morbi-mortalidade por causas violentas, mas sofre fortemente seu impacto e sua resposta a tal demanda é fundamental para minimizar as seqüelas decorrentes desse quadro, sendo de sua responsabilidade providenciar - a tempo - o tratamento adequado ao paciente vítima de acidente, violência ou outro mal que demande atendimento de urgência. 
Por outro lado, no caso do atendimento ao parto, a forma como está estruturado o atendimento médico de urgência é responsável por inúmeros problemas, inclusive pelo número bastante elevado das mortes maternas. TANAKA (1995) refere que, em sua pesquisa realizada na Região Sul do Municipio de São Paulo, "Das 52 morte maternas que tiveram como causas de falecimento complicações próprias associadas à gestação, ao parto e ao puerpério, 55,1\% tiveram de peregrinar até a morte. De 10,2\% das demais mulheres não se tem informação suficiente para saber se passaram ou não pela peregrinação, e apenas $34,7 \%$ foram internadas prontamente." (pág. 40). A esse quadro podem-se somar os casos levantados pela imprensa, quer seja de falta de pronto atendimento médico a casos de urgência, quer seja à inexistência de recursos físicos e humanos em determinados hospitais e prontosocorros.

A Constituição da República brasileira trata a saúde como um direito fundamental, elencando-a entre os direitos sociais (C.F.art.6 ${ }^{\circ}$ ) e estabelecendo que "legislar sobre proteção e defesa da saúde" é competência concorrente da União e dos Estados (C.F.art.24, XII), sendo que compete aos Municípios suplementar a legislação federal e a estadual no que couber (C.F.art.30, I). Assim, sempre que não se tratar de hipótese onde predomina o interesse local no tratamento da saúde, quando a competência legislativa é municipal (C.F. art.30, I), as três esferas de poder político da República são competentes para disciplinar as atividades de proteção e defesa da saúde, cabendo à União editar as normas gerais, que serão suplementadas pela legislação estadual e municipal. Por outro lado, "cuidar da saúde" é competência comum da União, dos Estados e dos Municípios (C.F.art.23,II).

Os constituintes de 1988 não se limitaram, contudo, àquele reconhecimento, tendo construido um sistema de saúde cujas bases essenciais estão abrigadas no próprio texto constitucional. Entre esses fundamentos encontra-se a necessidade de que as ações e serviços de saúde integrem uma rede regionalizada e hierarquizada, constituindo o sistema, que deverá, igualmente, organizar-se de modo a garantir atendimento integral (C.F.art.198, II). Isso significa que, em cada região, todas as ações de saúde devem ser realizadas de modo a garantir que cada problema identificado receba - na própria região - todo o tratamento indicado, requeira ele recursos de maior ou menor complexidade.

A partir da organização posta na Lei Maior, os constituintes puderam, nos Estados, fixar as normas que regulamentam, fiscalizam e controlam as ações e serviços de saúde em seu território, além, é claro, daquelas que organizam o sistema estadual de saúde. No Estado de São Paulo, foi privilegiada a organização regional na definição e na implementação das políticas públicas, tendo sido estabelecida a obrigação constitucional de criar - por meio de 
lei complementar - um conselho de caráter normativo e deliberativo para promover aquela regionalização (C.E. art. 154). Tal conselho ainda não foi criado e, portanto, para cada ação que suplante a área de abrangência de um Município é necessário que se estabeleça um acordo entre o Estado e os Municipios envolvidos. Entretanto, o Código de Saúde de São Paulo, lei complementar estadual $n^{\circ} 791 / 95$, ao definir as bases do Sistema Único de Saúde no Estado, estabelece a obrigação de conjugar a totalidade dos recursos físicos, materiais e humanos do Estado e dos Municipios na prestação de serviços públicos de assistência à saúde e de divulgar as informações quanto ao potencial desses serviços e à sua utilização adequada pelo usuário (art.12,II,c).

Para dar consistência ao sistema sanitário organizado na Constituição federal, foram aprovadas as leis n 8080 e 8 142, ambas de 1990, conhecidas como Lei Orgânica da Saúde. É nesse texto legal que se pormenorizam os principios e as diretrizes e as grandes funções envolvidas naquele sistema. Assim, encontra-se afirmada, por exemplo, a obrigação - para o sistema - de divulgar as informações quanto ao potencial dos serviços e sua utilização pelo usuário, assim como, a de apresentar serviços com capacidade de resolução em todos os niveis da assistência (Lei federal $n^{\circ} 8080$, art. $7^{\circ}$, VI e XII). Do mesmo modo que se esclarece a competência - e, portanto, a responsabilidade - da União, dos Estados e dos Municípios para fomentar, coordenar e executar programas e projetos de atendimento emergencial (Lei federal $n^{\circ} 8080$, art. 15, XXI). Fica claro, conseqüentemente, que, tanto a obrigação constitucional de legislar para promover e defender a saúde, quanto aquela de cuidar da saúde, inclui a responsabilidade pelo atendimento às emergências, que nenhuma esfera de governo pode ignorar.

A organização do atendimento às emergências na Região Metropolitana de São Paulo, após o mandamento constitucional que obriga a implementação de uma rede regionalizada e hierarquizada de ações e serviços de saúde com atendimento integral, teve inicio em julho de 1992, com a assinatura de um acordo básico interistitucional, pelo Governo Federal, o Governo do Estado de São Paulo e pelos Municípios da Região Metropolitana de São Paulo. Esse acordo - que nunca foi implementado - encontrava, como visto, apoio constitucional expresso no texto da Constituição do Estado de São Paulo (C.E.art.152, II e IV) e na Lei Orgânica da Saúde (especialmente, art.15, XXI).

A estrutura de gestão do atendimento às emergências na Região Metropolitana de São Paulo, conforme prevista naquele acordo interistitucional (de 6 de julho de 1992) e tendo por finalidade ordenar o atendimento de urgência na região, objeto do Programa 
Integrado de Atendimento Médico de Urgência, compreendia a existência de um Conselho Diretor, formado pelos Secretários de Saúde dos Municípios envolvidos, o Secretário Nacional de Assistência à Saúde e o Secretário de Saúde do Estado de São Paulo e de um Conselho Executivo. Ao Conselho Diretor competia definir as diretrizes e estratégias do programa; indicar os membros do Conselho Executivo; implementar o programa - fornecendo os meios necessários a seu perfeito funcionamento; e definir a Coordenação Médica Central. E ao Conselho Executivo, formado por 5 membros indicados pelo Conselho Diretor, competia a formação de Colegiados e Coordenações Médicas Regionais visando a integração dos serviços que atendem urgências médicas de forma regionalizada e hierarquizada; estabelecer mecanismos de coordenação entre regiões; estabelecer as normas operacionais dessa integração; desenvolver sistemas de informação gerencial e epidemiológica; indicar ao Conselho Diretor e aos Colegiados Regionais as necessidades de investimentos nas Unidades prestadoras; e propor alternativas operacionais para a criação de Central de Vagas Hospitalares na Região Metropolitana.

O Programa Integrado de Atendimento Médico de Urgência (PIAMU) implantado no âmbito do Sistema Único de Saúde do Estado de São Paulo a partir de 7 de outubro de 1992, tinha como principais características regionalizar e hierarquizar o atendimento médico de urgência, garantindo o atendimento, independentemente da existência de vagas hospitalares, conceito fundamental para a organização de sistemas de emergência, uma vez que neles não existe número fechado de leitos ou capacidade limite a priori. Assim, cada serviço que prestasse assistência deveria esgotar sua capacidade técnica de manter a assistência adequada. O programa contemplava o atendimento médico de urgência do adulto, da criança, da gestante e a atenção psiquiátrica.

Dando seqüência à proposta de implantação do PIAMU, verifica-se que a prefeitura do Município de São Paulo fez publicar no Diário Oficial de 31/10/92 a relação das unidades de referência do Sistema de Atendimento às Emergências, já regionalizadas e hierarquizadas. $\mathrm{E}, \mathrm{em} 1^{\circ}$ de dezembro, publicou as diretrizes que normatizam aquele programa no Município, esclarecendo que todas as instituições envolvidas tinham o direito de exigir comunicação por escrito (fax) para qualquer solicitação ou determinação de qualquer outra instituição e insistindo no princípio que não se pode considerar - para esse tipo de atendimento - o conceito de vaga: os espaços serão numerados e considerados como leito. E determinou, ainda que, a partir de 7 de dezembro de 1992, em teste, fossem intregradas as atividades da Coordenação do Projeto Resgate - Corpo de Bombeiros e SMS/CECOM (centrais de comunicação) no atendimento pré-hospitalar, invocando o Acordo Básico Interinstitucional de julho de 1992, e 
sugerindo que fossem envidados esforços para buscar, junto ao Sistema 190, a possibilidade de que a população tenha acesso a um número único para emergências.

Simultaneamente às providências de implantação do PIAMU no Município de São Paulo, o Estado iniciou, também, tal processo, publicando, em 27 de novembro de 1992 (Resolução SS-376) a grade de hierarquização e regionalização das Unidades de Saúde pertencentes à Região Metropolitana de São Paulo, esclarecendo que os encaminhamentos e fluxos das emergências obedecerão à normatização prevista no Acordo Básico Interinstitucional.

Curiosamente, não é possivel identificar qualquer ato que dê conseqüência à formalização desse acordo, que, conforme se verifica, orientou a atuação tanto do maior Município da Região quanto do governo do Estado. Assim, deduz-se que nunca foi criado e nomeado o Conselho Executivo, que teria a função de operacionalizar o programa, por delegação do Conselho Diretor. Entretanto, em 14 de janeiro de 1993, é publicada uma resolução do Secretário de Saúde do Estado de São Paulo (Resolução SS-17) instituindo uma Comissão Permanente para estudo e implantação do Plano de Atendimento Médico de Urgência no Estado de São Paulo (PAMU).

Em 1998 foi divulgado o Sistema de Regulação Metropolitano da Secretaria da Saúde do Estado de São Paulo, que visa coordenar o processo de reorganização do sistema de atenção às urgências de modo a causar impacto nos altos índices de mortalidade prevalentes na região. Esse sistema reforça a necessidade de integrar os sistemas 192 e 193 de atendimento pré-hospitalar, criando o Serviço de Atendimento Médico de Urgência - SAMU - parte do Sistema de Regulação Metropolitano da Secretaria de Estado da Saúde. Quanto à atenção hospitalar, insiste no princípio de que não será adotado o conceito de vaga, inovando, porém, com a inclusão de todos os leitos pertencentes ao Sistema Único de Saúde no sistema de regulação, uma vez que os hospitais privados fornecem parcela expressiva dos leitos da região. Outra inovação importante foi sua efetiva organização sistêmica, criando-se a Central Reguladora Regional - sob a gerência da Secretaria de Estado da Saúde -, que deverá agrupar o antigo Plantão Controlador Metropolitano (PCM) - que integrava os serviços que atendem urgências médicas de forma regionalizada e hierarquizada e estabelecia mecanismos de coordenação entre regiões e as normas operacionais dessa integração -, o SAMU e as outras centrais de vagas, buscando-se realizar a criação de Central de Vagas Hospitalares na Região Metropolitana, prevista no Acordo Básico Institucional de 1992. 
Apenas em julho de 1999, o Ministério da Saúde veio a disciplinar, por meio da Portaria $n^{\circ} 824,0$ atendimento pré-hospitalar no Brasil. Aprovando as Normas de Atividade Médica em Nivel Pré-hospitalar, essa Portaria estabelece, além dos critérios para "o atendimento que procura chegar à vítima nos primeiros minutos após ter ocorrido agravo à sua saúde", aqueles necessários à organização do sistema que permita atendimento regionalizado, hierarquizado e efetivamente integral ao paciente. O princípio de que, nas emergências, não existe número fechado de leitos ou capacidade limite a priori, é novamente reforçado. Além disso, tais normas obrigam, por exemplo, a existência de uma Central de Regulação, de fácil acesso ao público, onde o médico-coordenador despachará o atendimento à emergência. Assim, o médico regulador deverá ser competente para a gestão de outros meios disponíveis que não o leito hospitalar, devendo possuir autorização e regulamentação adequadas, em cada nível de gestão do SUS, seja estadual ou municipal.

A partir do levantamento das informações registradas no PCM será possivel descrever - em grandes linhas - o processo de atendimento às emergências médicas em São Paulo. Entretanto, somente a partir da observação simultânea de um Plantão Controlador Regional (PCR) e de algumas unidades de atendimento às emergências médicas, será possivel compreender aquele processo, verificando a adequação dos procedimentos adotados às normas que regem o setor e ao efetivo atendimento da demanda. Para buscar, então, o refinamento do quadro geral, optou-se por realizar esta pesquisa no Núcleo 4 -PCR MANDAQUI, uma das cinco divisões institucionais da Direção Regional de Saúde-DIR I, que, por sua vez, junto com as DIRs II, III, IV e V, corresponde às divisões administrativas da Secretaria de Saúde do Estado de São Paulo cuja competência geográfica se sobrepõe àquela da Região Metropolitana de São Paulo.

\section{OBJETIVOS}

A presente pesquisa, realizada entre julho e dezembro de 1.999, teve por objetivo geral descrever o processo de atendimento às emergências médicas em São Paulo, a partir da observação de um PCR, verificando a adequação dos procedimentos adotados às normas que regem o setor $e$ ao efetivo atendimento da demanda. Especialmente, se pretendeu observar o PCR do Mandaqui, descrevendo o processo de atendimento às emergências médicas; resgatar os dados documentais disponiveis sobre o processo de atendimento às emergências, tanto no PCR observado quanto no PCM; e verificar a adequação dos procedimentos 
adotados com a legislação concernente ao tema, em especial quanto ao direito à saúde constitucionalmente garantido.

\section{METODOLOGIA}

O Núcleo 4 - PCR MANDAQUI encontra-se instalado em uma das unidades de atendimento às emergências médicas, o Complexo Hospitalar do Mandaqui. Compõem esse núcleo 11 unidades de atendimento, com diferentes níveis de complexidade de recursos institucionais, materiais e humanos. Seu território de abrangência foi dividido em 6 regiões, obedecendo a critérios de acessibilidade física e complexidade de recursos. Pode-se afirmar, portanto, que existe uma sub-regionalização e hierarquização, identificando-se em cada uma dessas sub-regiões, pelo menos, um hospital cujos recursos disponiveis permitem sua classificação como "secundário". Nessas 6 regiões do Núcleo 4 foram escolhidos - para refinar o quadro geral descrito nesta pesquisa - três hospitais gerais, sendo dois de nível secundário e um terciário. A escolha desse Núcleo e das respectivas Unidades deveu-se, exclusivamente, à maior facilidade de transporte apresentada aos pesquisadores, uma vez que todos os Núcleos da DIR I apresentam características semelhantes às demais DIRs no que respeita às variáveis objeto desta pesquisa.

O levantamento da situação atual do sistema de atendimento de urgência na Grande São Paulo foi realizado através de pesquisa documental e de pesquisa de campo. Para um melhor entendimento do conceito de emergência e das possibilidades de estruturação de um sistema de atendimento às urgências e emergências médicas foi realizada pesquisa bibliográfica que revelou a inexistência de literatura nacional sobre o tema. Para melhor se conhecer como vem se construindo o Sistema de Emergência na Região Metropolitana de São Paulo foram realizadas entrevistas com profissionais ligados ao Plantão Controlador Metropolitano e analisados alguns documentos produzidos pelos serviços, tais como: regulamentos, ordens de serviço e outros documentos produzidos pelas secretarias de saúde municipais e estadual; escalas de plantão dos hospitais pesquisados, com a relação das especialidades disponiveis; taxa de ocupação dos hospitais pesquisados; por exemplo.

No primeiro momento da pesquisa de campo, foram realizadas entrevistas com administradores públicos responsáveis pelo sistema de atendimento médico de urgência. Num segundo momento foi realizada a observação in loco do funcionamento do sistema, proceden-

\footnotetext{
2 A pesquisa de campo foi realizada por Márcia Alves Guimarães, Milca Lopes de Oliveira, Nereide Falleiros Spina e Regina Macedo de Souza Nazareth, alunas da disciplina HSP 5714, em 1999.
} 
do-se ao levantamento de dados, através de formulário próprio preenchido pelos pesquisadores, junto aos hospitais e ao PCR. Nessa etapa, foi verificado o procedimento de pedido de vaga para transferência de pacientes, com o pedido dos respectivos recursos necessários, $\mathrm{e}$ o resultado de tais pedidos. Assim, havia um pesquisador observando o PCR do Mandaqui, ao mesmo tempo em que outros pesquisadores estavam observando as unidades, onde os chefes dos plantões eram acompanhados em sua rotina, no que tange aos pedidos de recursos para atendimento de emergência. Quando da solicitação de recursos, o pesquisador que estava acompanhando o PCR registrava a razão da solicitação e seu atendimento, especificando por qual unidade a solicitação fora atendida ou se ela fora transferida para o PCM. Os pesquisadores que estiveram acompanhando o chefe dos plantões nos hospitais registraram o recebimento das solicitações, com a especificação dos recursos solicitados, as respostas a cada solicitação e, quando não atendida, as razões para a negativa.

Para efeito da avaliação do funcionamento do programa implantado procedeu-se a uma comparação com o estabelecido na Resolução SS 376 (27/11/92). Para o levantamento dos dados utilizou-se um formulário próprio, com as seguintes variáveis independentes: hospital solicitante, recurso solicitado, motivo do recurso solicitado, instituição solicitada, tipo de resposta da instituição solicitada. Utilizou-se o Programa EPI INFO 6.0 para tabulação dos dados.

\section{RESULTADOS}

\section{A Historia Oral}

As entrevistas realizadas com profissionais atualmente envolvidos com o PCM (ainda não regulamentado), permitiram estabelecer uma história informal de seu processo de criação. A tentativa de se encontrar documentos comprobatórios dessa história revelou-se infrutifera.

No início dos anos 70, os plantonistas do Pronto Socorro do Hospital das Clínicas enfrentavam o congestionamento do referido Pronto Socorro. Em reuniões para tentar compreender o fenômeno, eles verificaram um fluxo intenso de pacientes encaminhados por diferentes instituições de assistência à saúde da Região Metropolitana de São Paulo, casos que poderiam ter sido resolvidos na instituição de origem e/ou na própria região. Decidiram, então, formalizar o elenco das prioridades que deveria ser respeitado no atendimento médico daquele Pronto Socorro. O grupo acabou por originar, em 1983, a Coordenadoria de Recursos e 
Assistência de Pronto Socorro - CRAPS, criada no âmbito da Secretaria de Saúde do Estado de São Paulo e, mais tarde, reativada - agora na Prefeitura do Município de São Paulo tendo funcionado por cerca de um ano.

Em 1988, a Secretaria de Estado da Saúde criou o Grupo de Programas de Urgência e Emergência Pré-Hospitalar - GEPRO, cujo objetivo era implantar, desenvolver, implementar e fiscalizar o programa de emergência em saúde. Esse programa, publicado em 1989, desenvolveu-se de maneira desarticulada, os critérios para o estabelecimento da grade de regionalização foram pouco discutidos. A Secretaria de Estado da Saúde, para fazer uma revisão da grade proposta, mapeou as áreas de abrangência dos hospitais terciários, delegando as responsabilidades pelo atendimento em cada área sem prévia consulta. Todo o processo durou 8 meses.

Com o estabelecimento dessa grade, o Pronto Socorro do Hospital das Clínicas - em 1989 - resolveu organizar-se, criando um plantão regulador para as emergências médicas em sua área de abrangência, chamado plantão administrativo. A experiência desenvolvida pelo Hospital das Clínicas permitia identificar possibilidades de treinamento em Recursos Humanos na área médica que melhor pudessem atender o funcionamento desse plantão. $O$ processo, com a institucionalização das reuniões de orientação sobre os casos encaminhados ao Hospital das Clínicas e a padronização de condutas e procedimentos clínicos, era informal. A adesão dos municipios era devida, principalmente, à legitimidade do Hospital das Clínicas. Os casos de áreas não abrangentes não eram aceitos, forçando-se - dessa maneira - uma organização por parte dos solicitantes.

Em 1990, durante um evento sobre neurocirurgia, voltou-se a discutir o problema da urgência e emergência na Região Metropolitana de São Paulo. Um grupo de profissionais se dispôs a rever a grade sugerida, mapeando - novamente - a área de abrangência de cada um dos hospitais terciários. Os profissionais hoje envolvidos com o sistema de urgência e emergência na Região Metropolitana de São Paulo identificam esse momento como o embrião de uma "política" para a área, aglutinando os serviços disponíveis nas várias instituições de assistência à saúde. Em 1992, fez-se a montagem de uma nova grade. Sentiu-se a necessidade de um Plantão Controlador que fosse mais eficiente e que aproveitasse a experiência do Hospital das Clínicas na orientação aos hospitais terciários. Aventou-se, também, o interesse na criação de consórcios, idéia logo abandonada por coincidir com o período eleitoral, que a inviabilizaria. 
É necessário notar que o processo ocorria informalmente, os acordos interinstitucionais dependiam da boa vontade e do compromisso social dos profissionais, que terminavam por envolver as instituições que se propunham participar de tal processo. Em um momento crítico a Secretaria de Saúde do Estado de São Paulo abandonou o processo e a Prefeitura do Município de São Paulo criou o PCM - inspirado na experiência do Hospital das Clínicas marcando o início de sua participação nas questões da emergência hospitalar.

O primeiro PCM funcionou em espaço cedido pela Prefeitura do Município de São Paulo, que the destinou 1 funcionário administrativo e 1 aparelho de fax, criando assim uma infra-estrutura mínima. A Secretaria da Saúde do Estado de São Paulo cedeu-lhe 3 linhas telefônicas, 2 funcionários administrativos e 1 computador. Naquele momento ficou acertado que cada hospital pertencente ao sistema do Plantão Controlador cederia 1 médico plantonista, com ônus para o próprio hospital. Cada hospital deveria formar o seu plantão controlador regional, não havendo uma articulação interinstitucional. Os PCRs não foram implantados, basicamente devido à necessidade de recursos humanos e de infraestrutura combinada com a inexistência de verbas para esse fim. Enquanto existiu, o PCM era dirigido por 4 médicos, cuja função era coordenar as reuniões e fazer os plantões funcionarem. Quando, em janeiro de 1993, o Secretário de Saúde do Estado de São Paulo instituiu a Comissão Permanente para estudo e implantação do PAMU no Estado, os hospitais municipais deixaram de fazer parte da grade de referência do PCM e, do mesmo modo, também seus plantonistas. Assim, o primeiro PCM funcionou, de maneira informal, durante 2 anos e 7 meses, quando foi atingido pela redução de recursos.

Em 1995, o PCM na Secretaria de Estado da Saúde foi extinto. Pretendia-se reestruturá-lo e criar uma central de vagas. Posteriormente - a partir de uma reunião do Conselho Estadual de Secretários Municipais de Saúde do Estado de São Paulo - COSEMS - foi iniciado um processo de re-mapeamento e identificação dos erros anteriores na implementação do PCM. Uma equipe fez um levantamento "in loco" nos Prontos Socorros dos hospitais e se verificou a necessidade de haver um plantonista em cada hospital, uma equipe treinada e a definição da grade de referência conforme às especialidades médicas. $O$ re-mapeamento indicava a necessidade da criação de um Sistema de Regulação, orientado pela lógica da necessidade. O grau de complexidade das necessidades indicaria as referências regionais a serem criadas, atendendo ao mandamento constitucional para a organização do Sistema Único de Saúde: integração das ações e serviços de saúde em uma rede regionalizada e hierarquizada. 
A Portaria n. ${ }^{\circ} 824 / 99$ do Ministério da Saúde, que disciplinou o atendimento préhospitalar no Brasil, alertou novamente as autoridades sanitárias da Secretaria de Estado da Saúde de São Paulo. E, embora ainda não esteja regulamentado, tem-se hoje, no Estado de São Paulo, um PCM, atrelado aos PCRs. Apesar de não inserido no Organograma da Secretaria de Estado da Saúde de São Paulo, o Sistema Regulador de Emergência tem um quadro funcional - com plantonistas médicos, telefonistas, funcionários com funções administrativas, computadores, fax, linhas telefônicas - previsto para trabalhar 24 horas diariamente. $O$ Estado de São Paulo paga os plantonistas do PCM e os plantonistas dos PCRs são pagos pelos seus respectivos hospitais, uma vez que atuam também como seus plantonistas. A lógica de funcionamento do sistema prevê a existência - em cada região - de Postos de Atendimento, de hospitais secundários, de hospitais terciários e de um hospital universitário. Deve haver uma tabela com os hospitais de referência para as diversas especialidades. Qualquer dos hospitais que precise transferir um paciente - após ter-lhe prestado os primeiros socorros necessários - deve notificar ao PCR de sua região (sediado no hospital terciário de referência para aquela região), que procura a vaga necessária, informando ao hospital solicitante, assim que a consegue. Caso o PCR não consiga resolver o problema dentro de sua região, ele deve procurar o PCM, que tem a responsabilidade de resolver o caso.

\section{A Atual Dinâmica da Rotina dos Serviços de Emergência Observados}

Verificou-se que os pedidos chegam ao PCR por via telefônica, na maioria das vezes, feitos por médicos de outros hospitais da região ou por médicos que conhecem o plantonista. O PCR observado, de acordo com o quadro funcional proposto, deveria ter dois atendentes e um médico de plantão. Durante a pesquisa, houve dias em que o médico plantonista não compareceu, tendo sido algumas vezes substituído. Entretanto, houve dia em que nem o plantonista designado nem seu substituto compareceram. Além disso, o médico de plantão no PCR muitas vezes tinha que atender a emergência do hospital. Essa duplicidade de funções fazia com que os atendentes não conseguissem localizá-lo nem em um nem em outro setor. Os pedidos feitos ao PCR ficavam, portanto, aguardando a chegada de algum médico para encontrarem solução. Os dois atendentes, nem sempre presentes simultaneamente no plantão, realizavam mais de uma função, atendendo à central de vagas de tuberculose e, muitas vezes, auxiliando o serviço de assistência social do hospital, confirmando dados de paciente. 
Observou-se, tanto no PCR, quanto nos hospitais, que os médicos responsáveis pelos plantões da emergência, não obedeciam a mesma rotina de procedimentos. Alguns achavam que os recursos deveriam ser procurados na região sem a interferência do PCR, julgando que $o$ atendimento aos casos de emergência seria mais ágil sem a presença de intermediários. Outros afirmavam desconhecer o procedimento correto e outros, ainda, conheciam e obedeciam a recomendação do PCM. Essa aparente anomia de procedimento pode explicar, por exemplo, a negação sistemática de todos os pedidos externos de internação na UTI Neonatal de um dos hospitais, justificada por um dos médicos plantonistas como arriscada para o berçário, em evidente agressão à lógica proposta. Cumpre notar que muitas vezes o PCR foi procurado em casos que não caracterizam a emergência médica ou que estão fora da região de abrangência. Isto ocorreu porque as pessoas - inclusive os médicos plantonistas - não sabiam o que é o PCR, confundindo-o com uma central de vagas. Por outro lado, foram observadas situações em que um hospital recusou a vaga quando foi procurado diretamente pelo médico atendente e aceitou o pedido de vaga quando formulado pelo PCR. Pôde-se verificar, do mesmo modo, que muitas vezes a falta de transporte impediu a transferência, pois o PCR não tinha ambulância. Percebeu-se, enfim, um descompromisso com o funcionamento do sistema, que se revelou nas declarações de discordância com as normas postas e na ausência ao local de trabalho.

Não se pôde conferir as informações sobre a inexistência de vagas devido à desatualização dos Serviços de Arquivo Médico e de Estatísticas - SAME - dos hospitais pesquisados. Apenas um dos hospitais tem um SAME atualizado, com o serviço informatizado. Em outro a falta de recursos humanos fez com que se estabelecesse uma única porta de entrada. Urgências, emergências, casos graves ou casos de ambulatório, pedidos de medicamentos ou de exames entram pela mesma porta. Observou-se que quando havia grande demanda ou falta de um funcionário, os poucos funcionários do SAME eram deslocados para cobrir a necessidade da recepção. Ficava, portanto, muito difícil a manutenção do sistema de estatísticas atualizado. Nesse serviço faltavam, também, recursos materiais, tais como computadores e aparelhos de fax. Em outro, ainda, o SAME fazia o registro dos atendimentos do Pronto Socorro em um computador, pela segunda vez, pois os atendimentos são, também, registrados em livro. O departamento de estatística fazia a coleta de dados e elaborava um mapa geral. Segundo um funcionário do PCR, anteriormente alocado naquele departamento, muitas vezes a enfermeira dá como vaga um caso que já teve alta, cujo leito, entretanto, já foi ocupado por ordem dos médicos da emergência, que transferiram um paciente estabilizado sem passar pelo SAME ou pelo PCR. O mesmo procedimento de mapeamento das vagas era realizado pelo médico do plantão na emergência. 


\section{Analisando as Informações das Observações "IN LOCO"}

1. as unidades

Percebeu-se que, geralmente, os hospitais solicitam a vaga diretamente para o chefe de plantão da equipe do PS ou para os especialistas que estão de plantão no dia, sem consultar o PCR. Essas solicitações são verbais, por via telefônica. Nos casos de hemodiálise, a solicitação é feita por fax. Durante o período de observação, muitas vagas foram cedidas porque o médico solicitante era - ou tinha sido - colega do médico plantonista. O exame de um caso com resposta negativa permite verificar a inoperância do sistema, pois foi possivel à diretora da Divisão Médica de um dos hospitais conseguir uma vaga que não havia sido conseguida - apesar de solicitada - pelo PCR. Em outro hospital, as vagas, segundo o médico de plantão na emergência, devem ser "guardadas" para as "especialidades". Porém as vagas de alguns setores podem ser ocupadas em casos urgentes. Apesar da não existência do conceito de "vaga" nos documentos pesquisados, as observações "in loco" permitiram a afirmação de que, nesse hospital, "faltavam vagas" na Clínica Médica e "sobravam" na Pneumologia.

\section{2. o plantão controlador regional (PCR)}

OPlantão Controlador Regional - 4 está localizado numa sala do Hospital do Mandaqui, onde 2 funcionários atendem 3 linhas diretas e 1 ramal telefônico. Não há aparelho de fax na sala. O PCR usa o fax da diretoria e seu computador não está conectado em nenhuma rede, nem mesmo interna.

Durante a pesquisa, apesar de a amostra não permitir generalizações, o quadro observado coincide com a impressão dos profissionais que atuam na área, que identificam como um dos "nós" do sistema de atenção à emergência na região metropolitana de São Paulo a falta de leitos para UTI Neonatal. Dentre os motivos apresentados para a solicitação de recursos, três foram os mais expressivos: falta de leito, falta de equipamento ou equipamento quebrado e falta de profissional. A falta de leitos para UTI neonatal é um dos principais motivos que levam os hospitais a recusarem a internação de gestantes em trabalho de parto, já que o hospital deve atender ao recém-nascido, inclusive quanto à necessidade de internação em UTI. A recusa de atendimento à gestante, por seu turno, conforme já observou TANAKA (1995), pode transformar em um quadro de emergência, por conseqüência da peregrinação da gestante em busca de atendimento, um caso de parto ordinário, ocasionando sérios agravos à saúde da parturiente e do nascituro, inclusive a morte. 
É interessante notar que das 19 solicitações acompanhadas, 15 tiveram uma primeira resposta negativa. Dois casos só encontraram solução depois que o pedido foi reiterado pela quarta vez. Os motivos mais freqüentes para a resposta negativa foram a falta de vaga, 0 equipamento não estar disponivel e a indisponibilidade de transporte. Depoimentos confirmaram que para alguns casos (ortopedia, por exemplo) não é difícil conseguir o recurso solicitado. Outros, porém, exigem muita procura e, às vezes, não se consegue transferir o paciente.

Pôde-se verificar que, em diversos dos casos acompanhados neste trabalho, foi necessário que o hospital solicitasse o recurso mais de uma vez apesar de algumas dessas instituições lidarem com uma crônica falta de recursos humanos. Por outro lado, pôde-se verificar, também, que a maioria dos casos examinados - 12 (63\%) - chegou ao PCR depois de ter procurado solucionar seu problema por conta própria (sem acessar o PCR), alegando a demora no encontro da solução como justificativa para esse comportamento. Um exemplo que ajuda a compreender o argumento empregado pelas instituições solicitantes foi observado durante a pesquisa. $O$ Hospital solicitante procurou por meios próprios o recurso em duas tentativas. Não tendo conseguido, buscou o PCR, que lhe telefonou - em seguida - para indicar o hospital preparado para aceitar a transferência do paciente. Entretanto, quando da ultimação dessa transferência o hospital indicado pelo PCR não aceitou o paciente - como havia sido definido - e o hospital solicitante foi, novamente, obrigado a tentar solucionar o problema.

\section{DISCUSSÃo}

A tentativa de construir, implementar e fomentar um Sistema Metropolitano de Atendimento de Emergência na região de São Paulo se arrasta há décadas. Ela é mais efetiva a partir de 1992. A Constituição, segundo CANOTILHO (1982) se apresenta como um "plano global normativo" endereçado ao Estado e à própria sociedade (p.12). É preciso buscar conquistar - em meio a interesses variados, desde os sanitários até aqueles que envolvem formas de produção, de administração da coisa pública, de financiamento, dentre outros - a implementação dos direitos que se quer garantidos. A existência de uma Constituição não é suficiente para que os direitos humanos sejam efetivamente respeitados e implementados. $A$ experiência internacional com o atendimento de emergência tem revelado a necessidade de tecnologias mais atuais estarem disponiveis, para que se possa maximizar e otimizar tanto os recursos quanto os resultados. 
A importância de um sistema controlador para orientar o atendimento à emergência e às eventuais necessidades de transferências de pacientes entre unidades de saúde no Município de São Paulo já foi suficientemente salientada (FERREIRA, 1999). Assim, parece oportuno e conveniente discutir os resultados desta pesquisa considerando-se a experiência estadunidense no tema. Isso porque, em ambos os casos, tem-se uma estrutura de Estado Federal cuja distribuição constitucional de competências assinala para os Estados e a esfera federal - concorrentemente - o dever de regular a matéria. Assim, nos Estados Unidos, os Sistemas de Emergência Médica (SEM) tiveram início em 1966. Pode-se afirmar que existe, hoje, um consenso sobre a necessidade de estabelecimento de uma agenda para o futuro que deve incorporar as inovações curriculares na formação dos futuros profissionais e privilegiar as ações das entidades que trabalham com atendimento de emergência - tanto voluntárias quanto lucrativas - para focalizarem a intervenção na identificação precoce e modificação dos fatores de risco antes que os agravos e danos à saúde aconteçam. No Brasil, apesar de as primeiras tentativas datarem do início dos anos 1970, há ainda pouca participação técnica e popular visando elaborar e implementar uma política de atendimento à emergência médica.

A partir da análise das pesquisas desenvolvidas por RINACA et al (1998), com 1000 questionários, e por DELBRIDGE et al (1998), componentes do comitê da EMS Agenda para o futuro, do Departamento de Emergência Médica da Universidade de Pittsburg e demais entidades a ela integradas, pode-se identificar um elenco de 14 atributos necessários ao fomento de um SEM, que - embora tenha como referência um sistema mais amplo do que o aqui analisado, uma vez que envolve, também, o que na cidade de São Paulo é coberto pelo projeto RESGATE - podem ser úteis ao exame da situação em questão. Em ordem de prioridade, o mais lembrado deles foi a necessidade de integração dos serviços de saúde, pois o SEM deve ser visto como um componente do sistema de saúde e o tratamento da emergência como parte do programa assistencial. O Sistema Metropolitano de Atendimento de Urgências e Emergências em São Paulo atende, em certa medida esse atributo, pois houve um re-mapeamento das instituições de referência e já é real, formalizado e efetivo o atendimento pré-hospitalar, numa articulação com o Serviço de Bombeiros e SAMU. Considerando apenas o Município de São Paulo, pode-se afirmar, também, que já é concreta a implantação do sistema. Entretanto, o relacionamento entre o PCM, os PCRs e os hospitais ainda demanda ajustes significativos se se pretende o avanço na construção de um SEM para a região metropolitana de São Paulo.

A existência de legislação e regulação foi atributo lembrado em terceiro lugar no referido estudo como indispensáveis à coordenação dos programas de âmbito nacional. Há ainda a necessidade de regulamentação no âmbito estadual, assegurando qualidade aceitá- 
vel e possibilidade de avaliação pela população. A legislação estadual deve prever modelos que permitam à direção médica local determinar os parâmetros específicos para as práticas do SEM, ajudando-a a identificar as necessidades de saúde da sua comunidade. Verificou-se que o Estado de São Paulo fez três tentativas para regulamentar o sistema, re-mapeando entidades e construindo grades de atendimento. Contudo, não conseguiu, ainda, formalizá-lo, exercendo plenamente sua competência normativa, que é concorrente no atendimento de emergência. O único instrumento normativo existente (a Resolução SS-376 de 27/11/92), que estabeleceu a grade de hierarquização e regionalização das Unidades de Saúde pertencentes à Região Metropolitana de São Paulo, apresenta fragilidade intrínseca, pois não possui poder juridicamente vinculante sobre os Municípios.

OPCM vem se desenvolvendo, desde seu início, nos anos 80 , de maneira desarticulada, através de processos informais, com acordos profissionais e institucionais, mas desprovido de uma integração e articulação institucional e política efetiva entre o Estado de São Paulo e os Municípios. A não instalação do Conselho Diretor do Sistema de Emergência deve ser interpretada como um sinal dessa desarticulação. Desencontros técnicos e políticos têm sido a causa das várias formas assumidas pelo serviço e da ausência de ação concreta conjunta. As entrevistas com funcionários do PCM evidenciaram o desejo de ver regulamentado o SEM para facilitar a articulação interinstitucional e, certamente, oferecer à população um atendimento de melhor qualidade, ao otimizar os recursos já existentes. Estar-se-ia, assim, contribuindo para a implementação do Sistema Único de Saúde, respeitando-se seus princípios constitucionalmente definidos.

RINACA et al (1998) e DELBRIDGE et al (1998) mostraram, também, que os recursos financeiros permitem manter o sistema num estado de prontidão considerada satisfatória, podendo-se estabelecer uma infraestrutura local de atendimento às necessidades básicas de saúde da população. E a existência de recursos humanos devidamente preparados é altamente valorizada (figurando em $4^{\circ}$. e $5^{\circ}$. lugar - respectivamente -entre os atributos mais reconhecidos dos SEM). Eles devem receber imunização contra doenças transmissiveis, equipamentos adequados de proteção e educação continuada. O PCM vem atuando com uma infra-estrutura mínima, tanto no que respeita aos recursos humanos (atendentes e plantonistas), quanto no que se refere aos recursos materiais (aparelhos de FAX, linhas telefônicas, que muitas vezes ficam congestionadas, dificultando os contatos e retardando os procedimentos necessários). A mesma falta de recursos se repete no PCR, às vezes com maior gravidade, pois o plantonista falta e não se providencia substituto. Também, a falta de sistemas de informatização adequados dificulta ainda mais a circulação das informações neces- 
sárias.

Além disso, as experiências internacionais em administração de serviços de emergências médicas, incluindo serviços de centros especializados e sistemas de telecomunicações como suporte para desastres da natureza (enchentes, vulcões, furacões, etc.), enfatizam a necessidade de se seguir um protocolo sistemático para todos os processos de atenção. Verificou-se que um protocolo padrão, bem estruturado e manipulado por profissionais devidamente treinados, reduz a possibilidade de improvisos, facilita a observação da rotina dos plantonistas, permite priorizar as chamadas e a alocação de recursos. Alguns critérios devem orientar a elaboração de um protocolo padrão para atendimento pré-hospitalar: criar um grupo administrativo e de advertência; treinar atendentes; estabelecer critérios para o desempenho dos profissionais da equipe; compor e treinar os profissionais para melhorar a qualidade do grupo; rever e priorizar o atendimento dos casos; treinar e avaliar os procedimentos dos atendentes; prover educação continuada aos atendentes (CLAWSON et al, 1998, p. 578). É necessário, contudo, lembrar que o sucesso no atendimento depende da permanente avaliação dos elementos do protocolo.

A experiência paulista revela, entretanto, que o próprio protocolo proposto para o funcionamento do PCM - descrito anteriormente - não tem obtido consenso e, portanto, obediência. Assim, quando foi perguntado a um dos plantonistas qual era o procedimento correto para o encaminhamento de um caso, ele respondeu que só deveria procurar o PCR depois de ter esgotado a busca na região. Outro, porém, salientou a importância de se seguir o caminho correto para solucionar os casos e lembrou, para ilustrar, o pedido (acompanhado durante esta pesquisa de campo) para a avaliação de um caso por especialista, cuja vaga fora negada pelo hospital de referência quando solicitada diretamente pelo hospital e cedida quando foi encaminhada pelo PCR. Alguns dos entrevistados alertaram para o fato de não ter sido proporcionado um treinamento para adequá-los ao sistema, tendo sido escolhidos para os plantões aqueles médicos que já estavam há muitos anos no hospital e que, portanto, supunhase conhecerem os recursos da região, dos hospitais, e do próprio hospital onde trabalhavam. Perde-se tempo e se vem perdendo, também, credibilidade. Foi o que se observou quando o PCM, acionado para busca de vaga, conseguiu obtê-la e a entidade que aceitou o pedido do PCM, rejeitou a comunicação do hospital solicitante, alegando que ele não pertencia à área de abrangência daquela regional. Ou o que se verifica quando se faz o encaminhamento para as especialidades sem qualquer consulta ao PCM. Também, a rotina interna dos hospitais ainda não incorporou os procedimentos destinados a atender o SEM. Assim, há duplicidade na procura das vagas nas enfermarias, que é realizada tanto pelo serviço de enfermagem 
quanto pelos próprios médicos plantonistas. Por outro lado, os médicos que trabalham nos serviços de pronto-socorro encaminham seus pacientes do setor de emergência para as enfermarias sem notificar o SAME. Observou-se, igualmente, alta incidência de busca de recursos por influência pessoal, fortalecendo o clientelismo e distorcendo um sistema de referência. Reforça-se $\mathrm{o}$ atendimento $\mathrm{a}$ interesses pessoais em detrimento de necessidades coletivas.

O conceito de indisponibilidade do recurso solicitado, fundamental à estrutura de qualquer sistema de atendimento à emergência médica, deveria ser um dos focos centrais de atenção do sistema de atendimento às emergências, objeto desta pesquisa. Observou-se, contudo, que a desatualização dos SAME e a ausência de efetiva rotina para sua atualização tornam impossível verificar a veracidade da informação dada como justificativa pelo hospital que se nega a receber um dado paciente. Outros "nós" críticos no sistema foram evidenciados nas entrevistas com funcionários do PCM e do PCR, principalmente no processo de referência. Pôde-se concluir que o que deveria ser uma ligação vertical entre os hospitais solicitantes, o PCR e o PCM, tem sido uma ligação horizontal ou em todos os sentidos: hospital e hospital, PCR e PCR, hospital e PCM, PCR e hospitais de outra região.

Os trabalhos de RINACA et al (1998) e DELBRIDGE et al (1998) alertam ainda para vários elementos imprescindiveis para a implementação de um SEM eficaz, que não foi possível identificar durante o estudo da experiência paulista com o tema. São eles, em ordem decrescente de importância: 1 . pesquisas em EMS, com investigação adequada para intervenção no sistema de $S E M ; 2$ a exigência de direção médica qualificada para o sistema de SEM, em cada Estado; 3. um programa de educação continuada em sistemas de SEM; 4. informação e educação popular em saúde; 5 . existência de programas de prevenção, integrando os profissionais em cuidados comunitários de saúde; 6 . acesso do público ao sistema por meio da implementação de um único número de chamada telefônica em todo o território nacional; 7. sistemas de comunicação eficazes. Cada chamada de emergência deverá ser recebida por pessoal que preencha requisitos de formação e experiência que o habilite a determinar a ação mais efetiva. Todas as chamadas deverão receber direção médica apropriada. A comunicação via Internet permite que os atendentes do sistema SEM recebam e compartilhem os dados com outros profissionais que têm informações importantes sobre seus pacientes e clientes, em tempo real. Serviços eficazes de comunicação são os instrumentos básicos para o tratamento das emergências médicas em situações de desastre $e$ devem ser incorporados na rotina de um SEM. Informações a tempo podem prevenir morbidade e mortalidade. Viabilizar sistemas de telecomunicações - via ondas de rádio, satélite ou ainda 
uma rede de microcomputadores - é uma excelente escolha para prevenir e reduzir agravos à saúde. A relação custo-benefício - considerando o alcance coletivo e o atendimento de massa, a exigência de garantia do direito à saúde e do respeito à vida - é alta, pois eles são relativamente de baixo custo, potentes, de fácil manuseio e manutenção e facilmente transportados. Uma telemedicina relativamente barata e eficiente, capaz de servir áreas distantes, é viável com o acesso à rede mundial de computadores (www). Existem exemplos do uso dessa tecnologia em circunstâncias difíceis, como distâncias remotas e populações desassistidas, empregando apenas linhas terrestres e Internet ${ }^{3} ; 8$. o sistema de SEM deverá orientar a definição dos cuidados e serviços nas comunidades, conformes às necessidades de saúde, indicando cuidados domiciliares de acordo com as circunstâncias do paciente $e$ avaliando os avanços tecnológicos e farmacêuticos - em termos de conveniência e efetividade - antes de serem difundidos; 9. a avaliação contínua deve englobar todos os aspectos do sistema e contribui para melhorar a qualidade do processo, podendo garantir a eficiência e efetividade do sistema de SEM.

A integração dos serviços de saúde, os sistemas de informação e os programas de prevenção, entretanto, não se apresentam como papéis tradicionais de um SEM, de acordo com os entrevistados por KOENIG et al (1998). Alguns dos serviços analisados se consideram muito atuantes quando se trata de funções tradicionais de assistência, isentando-se, contudo, das atividades ligadas à prevenção, educação e promoção da saúde. Outros têm procurado rapidamente se adaptar às mudanças da tecnologia, melhorando seus sistemas de informação. O estudo mostra que legislação e regulação são áreas tidas como "muito necessárias" pelos provedores de serviços de emergência.

Durante a pesquisa de campo pode-se verificar, também, alguns pontos de estrangulamento do sistema, tais como a dificuldade de acesso ao PCR e sua baixa resolutividade; a real carência de vagas de UTI neonatal e o número insuficiente de ambulâncias para encaminhamento dos casos de emergência; a aparente tolerância ao descumprimento do horário de trabalho de médicos plantonistas. Mas, certamente, a principal conclusão foi que a ausência de regulamentação estadual para um sistema que vem se mostrando real e que funciona baseado no compromisso social de profissionais e instituições de assistência à saúde, compromete a efetividade das ações tidas como prioritárias. Não há instrumento legal de coordenação e supervisão que permita viabilizar o controle da articulação interinstitucional. E, espe-

3 O Pacific Island Health Care Project, Hawaii é um deles, citado por GARSHNEK et al., 1999, p. 213-218 
cialmente, não há um protocolo consensual, que tenha sido pactuado e que seja seguido por todos os profissionais que atuam no PCM e PCR.

\section{CONSIDERAÇÕES FINAIS}

A pesquisa realizada permitiu verificar que, para a eficaz implementação de um sistema metropolitano de atendimento à emergência médica na Grande São Paulo, é preciso legalizar e regulamentar o PCM para estimular os municípios a atuarem de maneira integrada e articulada, inclusive quanto ao financiamento dos procedimentos de emergência, conformando uma central de regulação atuante, efetiva e compromissada. Além disso, há necessidade de que exista efetivamente um médico plantonista destacado para o "plantão controlador" em cada hospital. É preciso, também, formalizar um protocolo de atendimento e toda a equipe envolvida no SEM deve ser treinada e as funções dos atendentes e dos plantonistas dos "plantões controladores" devem ser normatizadas. Isso significa que, também, os profissionais que atuam no SAME, assim como as equipes dos serviços de pronto-atendimento, além daqueles especificamente designados para os "plantões controladores" devem conhecer bem a rotina de funcionamento do sistema. $A$ informatização de todas as unidades do SEM certamente contribuirá para melhor organizar o atendimento e tornará mais ágil a rotina, conforme se verificou em uma das unidades estudadas.

Sem a organização adequada e a informatização do SAME em todas as unidades do sistema, permitindo conhecer em tempo real a efetiva ocupação dos leitos hospitalares, será impossivel implementar o conceito de "inexistência de vaga". Além disso, a disponibilidade de leitos por especialidade deveria figurar atualizadamente na rede e ser acessivel para todas as entidades participantes do Sistema. Verificou-se, igualmente, que a falta de recursos materiais muitas vezes bloqueou o sistema, pois a existência de equipamento em manutenção num SEM é igual à inexistência desse recurso e, sobretudo, há necessidade de melhorar o sistema de comunicação para que as informações estejam disponiveis em tempo real, permitindo a redução dos riscos de mortalidade e morbidade.

Por outro lado, lembrando que se pretendeu verificar, igualmente, neste trabalho, a adequação do serviço analisado às exigências derivadas da afirmação constitucional do direito á saúde, é necessário reconhecer o potencial representado pela cidadania. Quando se analisa a evolução histórica da participação popular, culminando num processo de controle 
social institucionalizado, tem-se a impressão que assim como evolui o processo teóricopropositivo, de caráter ideológico, evolui também a prática sanitária-social. Isto não é real. Existe grande distância entre um direito garantido constitucionalmente e a real efetivação do direito à saúde para todos. Este cenário é o grande desafio para a ação dos conselhos de saúde, criados pela Lei $8.142 / 90$, que disciplinou o controle social previsto constitucionalmente. A consecução desse resultado interessa a cada indivíduo, em particular, mas interessa, também, ao sistema de saúde como parte do sistema de serviços públicos. Para atingir esse objetivo, é necessário que os destinatários dos serviços atuem permanentemente, por canais competentes e legalmente disponíveis, protegendo seus direitos e, ao mesmo tempo, colaborando com as autoridades públicas. A advocacia em saúde, "processo que utiliza conjunto de estratégias políticas visando a promover direitos não respeitados, através de meios legais e éticos, a favor de grupos sociais desfavorecidos ou oprimidos. Assim, a advocacia em saúde desenvolvendo ações que procuram influenciar autoridades e particulares, sensibilizando-os para carências e necessidades sanitárias diversas"(DALLARI et al., 1996, p. 593) pode ser um instrumento para a efetivação do direito à saúde. A população pode se valer de instrumentos constitucionais para atuar junto aos poderes legislativo, executivo e judiciário. Entretanto, por termos uma situação de cidadania regulada e alto índice de desinformação, não faz parte da cultura política de nossa sociedade ir aos tribunais reivindicar direitos sanitários, mesmo porque opinar na perspectiva da defesa de interesses coletivos exige informação, domínio dos instrumentos técnicos, etc.. Tampouco estão os juristas acostumados a esta rotina, o que, associado a reduzida informação técnico-científica, dificulta a tramitação de processos dessa natureza. No caso estudado, a Constituição Brasileira, a Lei Orgânica da Saúde, a Constituição do Estado de São Paulo e seu Código de Saúde fornecem os fundamentos e a normatização inferior indica as premissas do sistema que mesmo o Poder Judiciário pode exigir que seja implantado. Assim, para que o Sistema Metropolitano de Atendimento Médico de Emergência seja efetivo deverá, também, haver maior divulgação do funcionamento do sistema junto à população, orientando-a, inclusive, sobre a vantagem de que os encaminhamentos sejam feitos pela rede de serviços de saúde, ao invés de assumir ela mesma os ônus de sair à procura dos recursos. Além disso, o PCM deve ser efetivamente metropolitano, ou seja, deve ser responsável por garantir o atendimento à emergência médica em toda a região metropolitana, e o Sistema deve ser considerado - com todas as conseqüências dessa consideração - parte efetiva do Sistema Único de Saúde na Região Metropolitana de São Paulo, devendo, portanto, sofrer supervisão e avaliação continuada.

Finalmente, algumas medidas de caráter mais geral parecem ser indispensáveis ao favorecimento da eficácia do SEM. Assim, é preciso dar melhores condições de infra-estrutu- 
ra e adequar para o atendimento da emergência as unidades básicas de saúde e os hospitais secundários, para não congestionar as instituições de atenção de nível terciário. Entretanto, sem que seja realizado um investimento substancial - econômico, social e cultural - na criação de mais recursos para atenção neonatal, trauma, UTI e semi-intensiva na região metropolitana de São Paulo, o SEM não será eficaz, pois, nessas especialidades, apenas a melhor organização do atendimento não será suficiente face à inexistência dos recursos necessários.

\section{REFERENCIAS BIBLIOGRÁFICAS}

BRASIL. Constituição da República Federativa do Brasil, 1988. São Paulo, Editora Revista dos Tribunais, 1997.

BRASIL. Lei $N^{\circ} 8,080 / 90$; dispõe sobre as condições para a promoção, proteção e recuperação da saúde, a organização e o funcionamento dos serviços correspondentes e dá outras providências.

BRASIL. Lei 8142/90. Dispõe sobre as formas de participação da população no SUS.

CAMARGO, A. B. M. et al. Evolução da mortalidade por acidentes e violências em áreas metropolitanas. In: MONTEIRO, C. A. (org) Velhos e novos males da saúde no Brasil: a evolução do país e suas doenças. São Paulo, Hucitec/Nupens/USP, 1995. p. 256-67.

CLAWSON, J. J. et al. Effect of a comprehensive quality management process on compliance with protocol in an emergency medical dispatch center. Ann. Emerg. Med., 32(5):578$84,1998$.

DALLARI, S. G. et al. Advocacia em saúde pública no Brasil contemporâneo. Rev. Saúde Pública,30(6):592-601, 1996

DELBRIDGE, T. R. et al. EMS agenda for the future: where we are ... where we want to be. Ann. Emerg. Med., 31(2):251-63,1998.

SÃO PAULO. Constituição do Estado de São Paulo.

SÃO PAULO. Lei 791/95. Obriga conjugar recursos físicos, materiais e humanos do Estado e dos Municípios com intuito de prestar serviços públicos de assistência à saúde, bem como divulgar as informações quanto ao potencial desses serviços e a sua utilização adequada pelo usuário. 
FERREIRA, C. S. W. Os serviços de assistência às urgências no Municipio de São Paulo: implantação de um sistema de atendimento pré-hospitalar. São Paulo, 1999. [Dissertação de Mestrado - Faculdade de Medicina da USP].

GARSHNEK, V. Telecomunications systems in support of disaster medicine: applications of basic information pathways. Ann. Emerg. Med., 34(2):213-8,1999.

JORGE, M. H. P. M. "Morbi-mortalidade por violência”. In: CNPD. Anais do Seminário Nacional sobre Emprego e Violência. Brasília, 1996. Brasília, CNPD, 1998. p. 89-101.

KOENIG, K. L. et al. EMS systems and managed care integration. Prehospital Emerg. Care, 2(1):67-9, 1998.

MAMERI, C.P. et al. Uma questão de saúde pública. In: FUNDAÇÃO SEADE. Vinte anos no ano 2000: estudos sociodemográficos sobre a juventude paulista. São Paulo, 1998. p. 42-57.

MUNICÍPIO DE SÃO PAULO. Programa Integrado de atendimento médico de urgência. Região Metropolitana de São Paulo. Diário Oficial do Muicípio; São Paulo, 37 (226), terça feira, $1^{\circ}$. dezembro 1992.

RINACA, C. et al. EMS Agenda for the future: Virginia providers' perspectives. Prehospital Emerg. Care 3(2):150-6,1999.

TANAKA, A. C. D. Maternidade: dilema entre nascimento e morte. São Paulo, Hucitec/ Abrasco, 1995. 


\section{MEDICAL EMERGENCY SYSTEM IN THE METROPOLITAN AREA OF SÃO PAULO}

SUMMARY: The present paper analyzed the emergency medical system in the Metropolitan Area of São Paulo during the year 1999 through the exam of all the pertinent laws, the description of the attendance process of the Regional Controlling Unit (Plantão Controlador Regional - PCR), and the verification of the adequacy of the adopted procedures to the norms that regulate the sector and to an efficient attendance of the patients. Documents were analyzed, interviews were carried out and the functioning of the system was observed in the PCR and in three general hospitals. The paper describes the oral history of the creation of the system and the services routine. It was observed that there was personnel shortage in the PCR and that the doctors did not follow the same routine of procedures. It was also verified that many people, including the doctors on duty, did not know what the PCR was, and that transfers were sometimes impossible due to lack of transportation. Furthermore, the Medical Files and Statistics Services of the researched hospitals are outdated and there is shortage of material and human resources. Although the size of the sample does not allow generalizations, it could be observed that there was lack of beds in the Neonatal ICU, and that the most frequent reasons for the request of resources were lack of beds and equipment, faulty equipment and shortage of personnel. These requests often received a negative answer at first, with the most frequent reasons being lack of beds, unavailable equipment or transport. Most cases arrived at the PCR after the professionals in charge had tried to solve the problem on their own under the justification of delay in solving the case. Based on the rules of the system and on the analysis of international experiences, the paper provides suggestions for the efficacious implementation of a metropolitan emergency system in the metropolitan area of São Paulo.

KEY WORDS: medical emergency; health planning; health law.

Data de recebimento:20/03/2001

Data da aprovação: 24/06/2001 